\title{
AN ACHAEMENID ROYAL INSCRIPTION: THE TEXT OF PARAGRAPH 13 OF THE ARAMAIC VERSION OF THE BISITUN INSCRIPTION*
}

\author{
JAN TAVERNIER, Katholieke Universiteit, Leuven
}

\section{INTRODUCTION}

$T_{\text {HE longest and most studied text in the corpus of Achaemenid royal inscriptions }}$ is the Bisitun inscription (DB), in which king Darius I gives an account of the tumultuous first year of his reign. As is the case with most Achaemenid royal inscriptions, the text is recorded in Old Persian, Babylonian, and Elamite. When in 1911 Sachau published his text edition of Aramaic papyri in Egypt, ${ }^{1}$ however, it became clear that there was also an Aramaic version of this inscription (DB Aram.). This is hitherto the only preserved Aramaic version of an Achaemenid royal inscription.

This Aramaic version was written on a papyrus, the verso of which contains several columns of accounts. As can be deduced from the dates mentioned in these accounts, it seems certain that the Aramaic text was written on the papyrus in the early years of the reign of Darius II (around 421 B.C.), ${ }^{2}$ i.e., approximately a century after DB was carved on the rocks. There are several possible reasons for this. The copy could be an exercise of a master scribe. Yet it is more probable that the new copy was intended to commemorate the onehundredth anniversary of the accession of Darius I to the throne and of his suppression of

\footnotetext{
* Many thanks go to A. Schoors of the University of Leuven and S. Creason of the University of Chicago for their critical and helpful remarks. I would also like to thank the staff of the Chicago Assyrian Dictionary $(C A D)$ for its hospitality and access to its resources.

I am currently a Research Assistant for the Fund for Scientific Research-Flanders.

Abbreviations of texts cited follow the $C A D$ and the DNWSI (J. Hoftijzer and K. Jongeling, eds., Dictionary of the North-west Semitic Inscriptions [Leiden, 1995]), except for $A i W=$ Chr. Bartholomae, Altiranisches Wörterbuch (Berlin, 1904), and TAD A,B,C = B. Porten and A. Yardeni, Textbook of Aramaic Documents from Ancient Egypt, 3 vols. (Jerusalem, 1986-93). The Achaemenid Royal Inscriptions are cited according to the sigla established by R. G. Kent, Old Persian: Grammar, Texts, Lexikon, $2 \mathrm{~d}$ ed., American Oriental Series 33 (New Haven, Conn., 1953), pp. 107-15.
}

[JNES 60 no. 3 (2001)]

(C) 2001 by The University of Chicago.

All rights reserved.

0022-2968/2001/6003-0001\$02.00.
Other abbreviations used throughout are: Aram. = Aramaic, Av. $=$ Avestan, Arab. $=$ Arabic, Bab. $=$ Baby lonian, El. = Elamite, Heb. = Hebrew, Ir. = Iranian, OP $=$ Old Persian, Parth. $=$ Parthian, Sogd. $=$ Sogdian.

The Babylonian version of DB can be found in E. N. von Voigtlander, The Bisitun Inscription of $\mathrm{Da}$ rius the Great: Babylonian Version, Corpus Inscriptionum Iranicarum 1: Inscriptions of Ancient Iran, vol. 2, The Babylonian Versions of the Achaemenian Inscriptions, Texts 1 (London, 1978). The Aramaic version of $\mathrm{DB}$ (except for paragraph 13 ) is edited as TAD C2.1. For the Old Persian version of DNb, see W. Hinz, "Die untere Grabinschrift des Dareios," ZDMG 115 (1965): 227-41; N. Sims-Williams, "The Final Paragraph of the Tomb-Inscription of Darius I (DNb, 50-60): The Old Persian Text in the Light of an Aramaic Version," BSOAS 44 (1981): 1-7; R. Schmitt, "Bemerkungen zum Schlußabschnitt von Dareios' Grabinschrift DNb," Altorientalische Forschungen 26 (1999): 127-39.

${ }^{1}$ E. Sachau, Aramäische Papyrus und Ostraka aus einer jüdischen Militär-Kolonie zu Elephantine: Altorientalische Sprachdenkmäler des 5. Jahrhunderts vor Chr. (Leipzig, 1911). The edition of DB Aram. appears on pp. 185-205 and pls. 52 and 54-56.

2 Porten and Yardeni, Textbook, vol. 3, p. 61. 
the many rebellions that are described in DB. As both kings came to power in a fairly similar way, ${ }^{3}$ the recopying of the story that tells about the rise to power of Darius I was intended to identify Darius II with his well-known great-great-grandfather or at least to make a striking comparison between the two kings. ${ }^{4}$

This Aramaic text of DB has since been edited several times. ${ }^{5}$ As it is very close to the Babylonian version of DB, it has been generally assumed that it was based on that Babylonian version. ${ }^{6}$ For the sake of completeness, it should be mentioned that DB Aram. is closer to a Babylonian version of $\mathrm{DB}$, fragments of which were found in Babylon, ${ }^{7}$ than to the original Babylonian version carved on the rocks. ${ }^{8}$ Even so, this does not raise an objection to the use of the Babylonian version to reconstruct the Aramaic text. ${ }^{9}$ It should also be noted that the fragments do not contain the Babylonian parallel (or part of it) of DB Aram. paragraph 13. ${ }^{10}$

It is precisely this paragraph (DB Aram. 64-73) that this article intends to examine. It is the only part of the text that is not yet completely understood by scholars, and it is different from DB Bab. in two ways. First of all, DB Aram. 64-66a is not a nearly wordfor-word translation of the Babylonian text (as is the major part of DB Aram.), but it is taken from two separate Babylonian sections (44 and 52). Secondly, the middle part (lines $66 \mathrm{~b}-70 \mathrm{a}$ ) has no clear connection with any part of DB Bab. and has therefore puzzled scholars for a long time. ${ }^{11}$ This problem was solved, however, when in 1981 Nicholas

${ }^{3}$ Most information on the rise to power of Darius II and his accession to the throne is given by Ctesias, 18. 48-51 (no. 688 in F. Jacoby, Die Fragmente der griechischen Historiker, Dritter Teil: Geschichte von Städten und Völkern, $C$ : Autoren über einzelne Länder [nos. 608a-856] [Leiden, 1958]). See also D. M. Lewis, Sparta and Persia: Lectures Delivered at the University of Cincinnati, Autumn 1976, in Memory of Donald W. Bradeen, Cincinnati Classical Studies, n.s. 1 (Leiden, 1977), pp. 69-76; M. W. Stolper, "The Death of Artaxerxes I," Archäologische Mitteilungen aus Iran 16 (1983): 223-36; and Entrepreneurs and Empire: The Muraš̀̂ Archive, the Murašû Firm, and Persian Rule in Babylonia, Uitgaven van het Nederlands Historisch-archeologisch Instituut te Istanbul (PIHANS) 54 (Leiden, 1985), pp. 116-24.

4 J. C. Greenfield and B. Porten, The Bisitun Inscription of Darius the Great: Aramaic Version, Corpus Inscriptionum Iranicarum 1: Inscriptions of Ancient Iran, vol. 5, The Aramaic Versions of the Achaemenian Inscriptions, Texts 1 (London, 1982), p. 3; Porten and Yardeni, Textbook, vol. 3, p. 59.

5 A. Ungnad, Aramäische Papyrus aus Elephantine (Leipzig, 1911), pp. 83-97; A. Cowley, Aramaic Papyri of the Fifth Century BC (Oxford, 1923), pp. 24871; Greenfield and Porten, The Bisitun Inscription; Porten and Yardeni, Textbook, vol. 3, pp. 58-71 and foldouts $25-28$.

${ }^{6}$ Sachau, Aramäische Papyrus, p. 185, noticed this. See also Cowley, Aramaic Papyri, pp. 249-50; Greenfield and Porten, The Bisitun Inscription, pp. 516; Porten and Yardeni, Textbook, vol. 3, p. 59.
${ }^{7}$ Fragment BE 3627 (renumbered Berlin VA Bab. 1502 ) has been published by F. H. Weissbach, Babylonische Miscellen, Wissenschaftliche Veröffentlichungen der Deutschen Orient-Gesellschaft 4 (Leipzig, 1903; Osnabrück, 1978), pp. 24-26 and pl. 9. The other fragment, Bab. 41446, was published by R. Koldewey and F. Wetzel, Die Königsburgen von Babylon, 2: Die Hauptburg und der Sommerpalast Nebukadnezars im Hügel Babil. Wissenschaftliche Veröffentlichungen der Deutschen Orient-Gesellschaft 55 (Leipzig, 1932), pp. 23-24 and pl. 2. The most recent edition of these fragments can be found in von Voigtlander, The Bisitun Inscription, pp. 63-66.

${ }^{8}$ Greenfield and Porten, The Bisitun Inscription, p. 3.

${ }^{9}$ There are not too many differences, and they consist mainly of omissions on the fragments on the Aramaic text. The fragments represent thus a later version of the text. A comparison of both Babylonian versions has been made by von Voigtlander, The Bisitun Inscription, pp. 63-65.

${ }^{10}$ DB Aram. was divided by Greenfield and Porten into eleven paragraphs and by Porten and Yardeni into fourteen. The paragraph containing the Aramaic version of the last part of $\mathrm{DNb}$ is paragraph 10 (Greenfield and Porten) or 13 (Porten and Yardeni), i.e., the Aramaic lines 64-73. This article will follow Porten and Yardeni's division of the text.

${ }^{11}$ Sachau, Aramäische Papyrus, p. 197; Cowley, Aramaic Papyri, pp. 264-65. 
Sims-Williams showed that this middle section was an Aramaic translation of the last paragraph of Darius's tomb inscription DNb. ${ }^{12}$ This paragraph is actually an independent inscription, probably dictated by Darius sometime after DNb was carved on the rocks. ${ }^{13}$

Presumably, the Aramaic version of DB, which was written down at the royal court shortly after the accession of Darius II to the throne, already contained these two differences. ${ }^{14}$ The scribe who copied the papyrus apparently did not play an active role and refrained from editorial work. ${ }^{15}$

In addition to these two differences, some of the Babylonian text is not translated at all in paragraph 13. Paragraphs 12 and 14 correspond to the Babylonian sections 38 and 54 . The paragraph in question here at first sight contains only parts of the Babylonian sections 44,49 , and 52. Some of them (39-43) are in the lost Aramaic columns ix and x. ${ }^{16} \mathrm{Sec}-$ tions 45-48, 50-51, and 53 were not translated from Babylonian to Aramaic. ${ }^{17}$ The reason for these omissions is not known. Section 53 may have been omitted because it is primarily concerned with the preservation of the rock monuments, "a matter not pertinent to an account on papyrus." 18

The above-mentioned discovery by Sims-Williams proved to be a breakthrough in research on both this paragraph and DNb itself, as it helped scholars to reconstruct the last part of the latter inscription. Unfortunately, this breakthrough did not solve all the textual problems connected with DB Aram. There are still some unclear areas, which the two latest editions of this text do not deal with adequately.

What follows is a study of the textual problems of DB Aram. paragraph 13. The results of this study will be incorporated in a new edition of the reconstructed text, accompanied by a translation and a synoptic text. The text of this paragraph is divided into three parts: a warning against lies (64-66a), the Aramaic rendering of the last paragraph of DNb $(66 b-70 a)$, and a recommendation not to conceal the truth $(70 b-73)$.

\section{The Textual Problems in DB Aram. Paragraph 13}

\section{DB Aram. 64-66a: The Warning against Lies}

This section of DB Aram. seems to correspond to both Babylonian sections 44 and 52 . It is, in fact, an abbreviated version of these two parts. The introductory phrase presents no problems: throughout DB Bab., Dariamuš šarru kiam iqabbi corresponds to Aramaic dryhws $m l k^{\supset} k n^{2} m r$, so the restoration in Aramaic line 64 is quite obvious. That Aram. [mn $\left.{ }^{2} n\right] t$ mlk zy ${ }^{3} h r y$ thwh is the same as Bab. mannu atta šarru ša arkia tellâ is also clear. As

12 N. Sims-Williams, "The Final Paragraph of the Tomb-Inscription of Darius I," pp. 1-7.

${ }^{13}$ I. Gershevitch, "The Alloglottography of Old Persian," Transactions of the Philological Society, 1979 , p. 130.

${ }^{14}$ See my article "The Origin of DB Aram. 6669," Nouvelles assyriologiques brèves et utilitaires, 1999/86.

15 The other, and unlikely, possibility is that the scribe of this papyrus did the editorial work himself and that the differences are the results of this editorial work (Hinz, "Großkönig Darius und sein Untertan," A
Green Leaf: Papers in Honour of Professor Jes P. Asmussen, Acta Iranica 28 [Leiden, 1988], pp. 475 and $477-78$ ).

${ }^{16}$ Greenfield, and Porten, The Bisitun Inscription, pl. 1 and Porten and Yardeni, Textbook, vol. 3, foldout 28: column ix corresponds to Babylonian lines 84-89 (secs. 39-40), while column $\mathrm{x}$ corresponds to lines 89-97 (secs. 41-43).

17 Greenfield and Porten, The Bisitun Inscription, p. 5, argue that parts of secs. 45-48 may have been abbreviated in Aramaic lines 65b-66a and 70b.

18 Ibid., p. 5. 
this is a general introductory formula, it is hard to determine what Babylonian section is translated here. If one stresses the analogy between the Aramaic and the Babylonian word order, then clearly the Aramaic text is taken from DB Bab. 97 (sec. 44), since in the other two Babylonian occurrences of this phrase, the verb is not the final word of the sentence: mannu atta šarru ša tellâ arkia (secs. 52 and 55, lines 105 and 112). It should be noted, however, that word order is a rather weak basis for determining what section was translated here. In all probability, the author of this version of DB Aram. did not have a particular Babylonian section in mind when he wrote down this part of the text.

After this introductory formula, the Aramaic text describes a man who lies: ${ }^{2} y \check{s} z y$ ykdb. There are two possible Babylonian equivalents of this phrase: la tusaddad amēlu $\breve{s} a$ uparrașu (sec. 44, line 97) and amēlu ša uparrașu u amèlu pirkāni la tarâm (sec. 52, lines 105-6). As the expression zy ykdb occurs twice in this passage (lines 64 and 65), one can expect that both Babylonian phrases will have been translated. It is more difficult, however, to determine which sentence was translated in line 65 and which one in line 66 .

Most likely, Babylonian section 44, where the introductory formula is followed by lapani pirșātu lu mādu uṣur ramanka, is not the source for the Aramaic text after the introductory formula; for in that case not ${ }^{\supset} y \check{s} z y y k d b$, but $m n k d b n \check{s} g y^{\supset} n{ }^{\supset} z h r$ should be the words following the introductory formula. The author thus inserted one phrase from section 52 before translating section 44 .

Accordingly, Aram. ' $y \check{s} z y y k d b[\ldots] \mathrm{x}$ (lines 64-65) is the equivalent of Bab. amēlu ša uparrașu u amèlu pirkāni la tarâm. Two parts of this phrase are preserved: the beginning ( ${ }^{3} \breve{s} z y$ ykdb) and some traces of its last letter, the letter to the left of the break in line 65 . Porten and Yardeni do not believe this, however, They restore $[\mathrm{rh}] q$, and by connecting this form with the following $m n$, they arrive at $r h q m n k d b n \check{s} g y^{2} n$, "[withdr]aw from great lies." The next word ( $z h r$ ) they consider to be a separate sentence, meaning "take heed."19 The Babylonian text, however, has no such sentence consisting of only one verb. Consequently, ${ }^{\supset} z h r$ has to be connected with $m n k d b n \check{s} g y^{\supset} n$. This sentence corresponds precisely to the Babylonian version $\left(m n=\right.$ lapani, $k d b n=p i r s ̦ a \bar{t} u, ~ \check{s} g y^{2} n=m \bar{a} d u,{ }^{2} z h r=u s ̦ u r$ ramanka), while the preceding [. . .]x has to be the end of the sentence, which begins with ${ }^{3} y \check{s} z y$ ykdb in line $64 . .^{20}$

Although it is now quite certain that the first half of line 65 once contained the Aramaic rendering of $u$ amēlu pirkāni la tarâm, only part of the Aramaic version can be restored. ${ }^{21}$ In analogy with amēlu (line 105) - $y \breve{s}$ (line 64), it is acceptable to restore here ${ }^{2} y \breve{s}$, despite the fact that there is an exception to this equation: in line 65 the Aramaic rendering of Bab. amēlu is certainly not ${ }^{2} y \breve{s}$.

Let us turn now to the Aramaic rendering of la tarâm. Some scholars believe that a restoration [ $\left.{ }^{2} \mathrm{lt} h \mathrm{~h}\right] \mathrm{m}$ in line 65 is not possible because "the remains of the letter to the left of

${ }^{19}$ See Porten and Yardeni, The Bisitun Inscription, p. 71, where they also consider another translation: "withdraw. From great lies guard yourself." In that example, the verb $r h q$ is a separate sentence.

20 This possibility has already been mentioned by Greenfield and Porten in The Bisitun Inscription, p. 47.

${ }^{21}$ Perhaps the question should be asked whether there could be a connection between Bab. pirkānu and Aram. prk, "to damage, to break" (DNWSI, p. 938). The form yprk is attested once in a Lydian-Aramaic bilingual (KAI 260:6: $m n$ zy yhbl ' ${ }^{2} w$ yprk $m n d^{C} m$, "whoever destroys or does damage to anything").
The Akkadian word pirku has a broad meaning: "violence, difficulty, slander, evil." It is especially used during the Neo-Babylonian (in letters) and Achaemenian periods. See Stolper, Entrepreneurs and Empire, p. 280 at no. 112. See also his article "No Harm Done: On Late Achaemenid pirku Guarantees," in J. Marzahn and H. Neumann, eds., Assyriologica et Semitica: Festschrift für Joachim Oelsner anläßlich seines 65. Geburtstages am 18 Februar 1997, AOAT 252 (Münster, 2000), pp. 467-77. 
the break can hardly be a mem." 22 This, however, should not be assumed. The traces to the left of the lacuna have mainly been seen as belonging to a $q,{ }^{23}$ but a closer examination of the photographs suggests that the visible traces could be the upper left corner of a $d, k$, $q, r$, or even an $m$. In the latter case $(m)$, the text of line 65 would read [ $]^{\top} m^{\top} m n k d b n$ $\check{s} g y^{\supset} n{ }^{\supset} z h r$, which makes the restoration [ $\left.{ }^{\supset} l \mathrm{tr} h\right]^{\top} m^{1}$ still possible.

The next clear words in DB Aram. 65 are $z y y k d b$. Between them and the end of the last sentence, i.e., ${ }^{3} z h r$, there is space for one word of approximately four letters, which most probably corresponds to Bab. amélu. One would expect $w^{\supset} y \check{s}$ because it is the equivalent of amelu in line 64, but this certainly does not appear in this line. The first letter of the word was read by Sachau (and subsequently by Ungnad, Cowley, and Greenfield and Porten) as ayin. ${ }^{24}$ Porten and Yardeni, however, proposed the restoration $k[d] \dot{y} b$, "liar." ${ }^{25}$ If this is correct, the translation would be "a liar who lies." This is a possible restoration, since cognate accusatives occur often in Imperial Aramaic. ${ }^{26}$ Yet, if one chooses to restore a form of the root $k d b$, it would be better to restore $k[d] b$, based on $T A D C 1.1: 133$ ( $l k d b^{\supset}$ "for the liar"). ${ }^{27}$ The main objection to this restoration is that the evidence gleaned from the photographs indicates that the first letter of this word is more likely an ayin than a $k$. The word could thus be ${ }^{c}[l y m]$, "servant" 28 (cf. DB Aram. line 19: ${ }^{c} y l m y$, a scribal error for ${ }^{c}$ lymy. ${ }^{29}$ See also TAD B3.9:3). Such a restoration is not incompatible with what remains of the lower parts of the restored letters. The reason the author used the word "servant" instead of the word "man" is perhaps because he had another group of words in mind, for example OP marika, Bab. qalla, the usual Aramaic rendering of which is "lym. ${ }^{30}$

Clearly, ${ }^{\complement}[l y m$ ? $] z y$ ykdb is the object of a verb that means "do not care for, do not trust." Since the author was most likely translating Babylonian section 44, he inserted here the Aramaic equivalent of Bab. suddudu, "to take care of, to care for." ${ }^{31}$ This verb occurs more than once in DB Bab., but unfortunately, of all its occurrences, only one has been translated and/or preserved in the Aramaic version of DB. The Babylonian sentence șābu agannûtu u zèrāni ša șābu agannûtu lu mādu suddid, "fully protect these men and the descendants of these men" (line 112), is rendered in the Aramaic version $\operatorname{lzr}\left[{ }^{C} \mathrm{hwm} z y \mathrm{gbry}{ }^{2}\right.$ $\left.{ }^{2} l k \check{s} g y^{\supset} b p r\right] s^{\supset} s b l,{ }^{32}$ "the seed of those men, fully with allotment support." The verbal form $s b l$ ( $p a^{\complement c} e l$ imperative from $s b l$, "to support, to sustain") ${ }^{33}$ is the equivalent of suddid (D imperative from $s u d d u d u$ ). Keeping this in mind, we can possibly restore the lacuna in line 66 by inserting ['l tsblhy]. The translation of this sentence would be: "a man who lies, [you will not care for him].". 34

${ }^{22}$ Greenfield and Porten, The Bisitun Inscription, p. 47 .

${ }_{23}$ Ibid., p. 46; Porten and Yardeni, Textbook, vol. 3 , p. 7 .

${ }^{24}$ Sachau, Aramäische Papyrus, p. 196, line 2; Ungnad, Aramäische Papyrus, p. 90, line 2; Cowley, Aramaic Papyri, p. 253, line 51; Greenfield and Porten. The Bisitun Inscription, p. 46, line 65.

${ }^{25}$ Porten and Yardeni, Textbook, vol. 3, p. 70.

26 T. Muraoka and B. Porten, A Grammar of Egyptian Aramaic, Handbuch der Orientalistik, Erste Abteilung, Der Nahe und Mittlere Osten, vol. 32 (Leiden, 1998), p. 272.

${ }^{27} K d y b$ is a qatill-form. This type of form is mostly used for adjectives or passive participles. In Aramaic, a nomen agentis usually is a qattăl-form. See $\mathrm{H}$. Bauer and P. Leander, Grammatik des Biblisch-Aramäischen (Halle a.d. Saale, 1927), pp. 188 and 191.

${ }^{28}$ DNWSI, pp. 854-55.

29 Ungnad, Aramäische Papyrus, p. 85; Cowley, Aramaic Papyri, p. 260; Greenfield and Porten, The Bisitun Inscription, p. 31.

${ }^{30}$ Greenfield and Porten, The Bisitun Inscription, p. 62 .

${ }^{31} C A D$, vol. S, p. 342.

32 Restoration by Greenfield and Porten, The Bisitun Inscription, p. 52.

${ }^{33}$ DNWSI, p. 774.

34 See Muraoka and Porten, Grammar, par. 79, especially $b$. 
One problem with this restoration, however, may be the word order, since the Aramaic text usually has exactly the same word order as the Babylonian. ${ }^{35}$ The restoration proposed here would be an exception to this rule. In the Babylonian version (la [tusad ${ }^{\top} \mathrm{dad}^{\top}$ amèlu ša uparra ${ }^{\top} \leq u^{\top}$ ), the verb (tusaddad) occurs at the beginning of the sentence, while in the Aramaic version ( ${ }^{C}[\operatorname{lym}(?)] z y$ ykdb ${ }^{\prime} l$ tsblhy) the verb (tsblhy) would be at the end of it, i.e., in line 66 , but this would not be the only example of a different word order. Other examples (phrases under discussion are in italics) are:

1. Bab. 51-52: arki ina šanītu harrānu nikrūtu iphurūnimma ana tarṣi mDadaršu ittalku itti uqu ana epēš tāhnāzi.

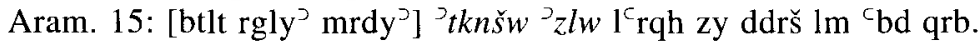

Then for another expedition (Aram., for the third time) the rebels rallied and marched against Dadaršu (Bab., with troops) to join battle.

2. Bab. 74: ' 'Umizdātu ... it [ti ] uqu ittalak ana tarṣi mArtamarzi ana epēš tāhnāzi. Aram. 41-42:[Wyzd]t ... ${ }^{3}$ th $\left[^{C}\right] m$ [hyl ${ }^{P} 1^{C}$ r]qh [zy ${ }^{3}$ rtwrzy] $\operatorname{lm}\left[{ }^{C}\right] b d \mathrm{q}[\mathrm{r}] \mathrm{b}$.

(This) Vahyazdāta . . . marched with his troops to join the battle against Artavarziya.

3. Bab. 77: 'mU[mi]zdātu u mārē banē ša ittišu uṣsabbitu ṣabtu.

Aram. 48: Wyzdt ${ }^{\circ} h d w$ whir ${ }^{\supset}$ zy ${ }^{\ulcorner} \mathrm{m}[\mathrm{h}]$.

They took captive Vahyazdāta and the nobles who were with him.

4. Bab. 79: uqu . . išpurma iltapar ana 1-en amēlu. . . .

Aram. 51-52: [hyl ${ }^{\supset} \ldots$. šl w $^{\supset}$ yš ḥd ... [šlh].

He (= Vahyazdāta) had sent troops, and he had sent an order to a certain man. ... (Aram.: he had sent a man).

These four examples show that differences in word order between DB Bab. and DB Aram. do occur and that the different word order here does not affect the plausibility of the proposed restoration.

Despite the reconstruction ['l tsblhy], there is still some space left in the first half of line 66. ${ }^{36}$ Perhaps one should restore here a hitherto unattested Aramaic equivalent of Bab. $l u$ $m \bar{a} d u \check{s} \bar{a} l \grave{s} u$, "vigorously prosecute him." In that case, one of the words in the restoration may have been $\check{s} g y^{2}$, based on the equivalence of $\check{s} g y^{3}$ and $m \bar{a} d u .{ }^{37}$ Another, more probable, possibility for the Aramaic rendering of the verb "interrogate" (OP ufrastam ${ }^{38}$ frat $^{-}$, Bab. mādu šâlu, El. mil hapi) is hssn $\check{s}^{2} l$ (TAD A6.8:3 and A6.10:9). Consequently, I restore it as $\left[h s n \breve{s}^{\prime} l h y\right]$, which fits nicely in the space available.

${ }^{35} \mathrm{Cf}$. the line-for-line parallel translations in Greenfield and Porten, The Bisitun Inscription, pp. 6-13.

36 This gap cannot be filled by inserting a vocative, which would be connected with the following phrase, as in the original text (the vocative being marika $\bar{a}$, $\mathrm{O}$ subject"). Here Darius is giving advice to his successor rather than to his subject (Sims-Williams, "The
Final Paragraph of the Tomb-Inscription of Darius I,' p. 2).

${ }^{37}$ Greenfield and Porten, The Bisitun Inscription, p. 62 .

${ }^{38}$ DB IV 38 and 69; sometimes ufraštam (DB I 22 and IV 66-67). 
Based on my conclusions thus far, the text of lines 64-66a appears as follows:

(64) [dryhwš mlk $\left.{ }^{\supset} \mathrm{kn}^{\supset} \mathrm{mr} \mathrm{mn}{ }^{\supset} \mathrm{n}\right] \mathrm{t} \mathrm{mlk}$ zy ${ }^{\supset}$ ḥry thwh ${ }^{\supset} \mathrm{yš} \mathrm{zy} \mathrm{ykdb}$

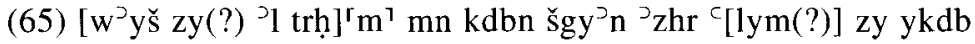

(66) ['1 tsblhy ḥsn š̉lhy]

\section{DB Aram. 66b-70: The Aramaic Translation of DNb Paragraph 9}

At this point (line 66b), the Aramaic translation of the last paragraph of DNb begins. ${ }^{39}$ Since the rest of DB Aram. is based on DB Bab., one would expect that this part is based on the Babylonian version of DNb by analogy; yet this is not the case. It is more likely that the text is taken from the Old Persian text of DNb. One indication for this is that two words of the Old Persian text (paratar and ayāumainiš) appear on the papyrus in transcription ( $p r t r$ and ${ }^{2} y m n \check{s}$ ) rather than in translation. ${ }^{40}$ An additional argument is that only in the Babylonian text (line 37) does the subordinate clause, "what he who is not freeborn does," follow the main clause, "look at that." In the three other versions of DNb, the subordinate clause precedes the main clause:

DNb Bab. 37

DNb OP 56-57

agāšû am[u]r šá muškē[na ippušu]

DB/DNb Aram. 68

tya [skauசiš kunav]ātaiy (57) avaščiy dīdiy

DNb El. 40-41

zy mskn ycbd zk hrzy

[ap]pa [v.i-ip-ik-ra] hu-ud-da-man-ra hu-[be] zí-ia-i[š $]^{41}$

As DNb OP 50-60 appears to be the source for DB Aram. 66b-70a, it might be useful to begin the analysis of this passage with the Old Persian text (for bibliographical references, see the asterisked note on p. 161 above):

§9. (50) marīkā : daršam : azd[ā] : $\mathrm{ku}^{\mathrm{n}} \check{\mathrm{s} u[v \bar{a}}$ : čiyā] $\mathrm{karam} \mathrm{(51):} \mathrm{ahiy} \mathrm{:}$

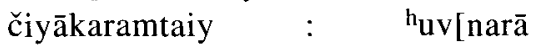
čiy]ākara(52)mtaiy : pariyanam mātaiy : [ava vahiš]tam : (53) $\theta \mathrm{a}^{\mathrm{n}}$ daya : tyataiy : gaušāyā : $\theta[$ ahyātiy :] avaš(54)čiy : àxšnūdiy : hya : pa[ratar : Өahy]āti(55)y : marīkā : mātaiy :ava [: naibam $\theta a^{\text {ndaya }}$ tya $\quad \mathrm{da} \theta \mathrm{a}(56)^{\mathrm{n}} \mathrm{s}$ ?]: ku[na]vātaiy : tya : [skau $\theta$ iš : kunav]ātaiy (57): avaščiy : didiy : marīkā : [6 tekens] : mā : (58)parāyātaya : a-[5 tekens] : mā[patiy : š]iyātiy(59)ā : ayāumainišs : bavāhiy : [marīka : avara]diya $(60): m \bar{a}: \operatorname{rax} \theta \mathrm{a}^{\mathrm{n}}$ tuv : u[tā : dahyauvā : mā : dāra]iya :

${ }^{39}$ The reason why this particular text was incorporated in DB is uncertain. Hinz, "Großkönig Darius," pp. 477 and $480-81$, believes that the Aramaic scribe who first made the insertion was highly impressed by the moral value of Darius's words and wanted to make them known to everyone.
$\S 9$. Young man, make in a large measure known of what kind you are, which are your gifts, of what kind your conduct is. Let not that seem best to you which one whispers in your ear. Rather, listen to what is said openly. Young man, let not that seem very good to you what the freeborn man does. Rather, look at what he who is not freeborn does. Young man, do not achieve your goal ... neither be unfit in your prosperity. A negligent man will not prosper, and in his country he will not live.

${ }^{40}$ Sims-Williams, "The Final Paragraph of the Tomb-Inscription of Darius I," p. 2.

${ }^{41}$ Restorations according to W. Hinz and H. Koch, Elamisches Wörterbuch, Archäologische Mitteilungen aus Iran, Ergänzungsband 17 (Berlin, 1987), p. 712 . 
Unfortunately, the papyrus is partly destroyed. Only the second half is preserved. Despite the fact that the content of the lost text is quite well known, it would be very difficult to restore any of the original Aramaic text. Four specific places in the text can be dealt with, however.

The first place occurs in the first half of line 67. There the Aramaic translation of OP mätaiy [ava fräa] mam $\theta a^{n}$ daya, ${ }^{42}$ "let not that seem best to you" should be restored. A similar construction is not attested in Old or Imperial Aramaic. Yet there are some texts in which some similar expressions occur, for example, $h n^{C} l m r^{\supset} n t b$, "if it is good to our lord" (TAD A4.5:19,21; 4.7:23, 4.8:22); $h n c l m r^{2} y t b$, "if it is good to my lord" (TAD A6.3:5); and $h n{ }^{C} l y k t b$, "if it thus be good to thee" (TAD A6.7:8). Possibly the same type of construction was used by the author of this text, so a part of the restoration could be $\left.\left[{ }^{\jmath} l{ }^{C} l y k t b\right]\right]^{43}$ The end of the missing text can be easily completed: $\left.z y b^{\supset}\right] d n k$ (= OP tyataiy gaušāyā) ${ }^{44}$

In the next line (68), the same type of sentence can be restored: ${ }^{45}\left[{ }^{\supset} l{ }^{\complement} l y k t b z y \ldots y\right]^{c} b d$. Here it is also possible to reconstruct the subject of $y^{c} b d$ on the basis of the sentence that follows $z y$ mskn $y^{c} b d z k h z y$, "that what he who is not freeborn does, look at that." The word we are looking for must be the counterpart of $m s k n$, i.e., $b r h r n$, "free man, nobleman," a term that is also attested elsewhere in Imperial Aramaic ${ }^{46}$ and that is even a common Semitic form. ${ }^{47}$ The restoration $\left[{ }^{3} l{ }^{\complement} l y k t b \text { zy } b r h r n y\right]^{\complement} b d$ makes it impossible to expect an Aramaic verb rendering OP $\theta a^{n}$ daya because there is not enough space for such a restoration in line 68.48

The third place in the text is the first half of line 69. Here a restoration is problematic, since the Old Persian text itself is damaged and OP [par] $]$ ayatay $a^{49}$ is not completely clear. Possibly, this verbal form consists of the prefix para-, followed by a causative of the root yat- (Av. yat-, Parth. $y^{\supset} d$-, Sogd. $y t$ ). This root has the meaning "to reach his natural place, to reach his destination, to reach his goal.",50

The only preserved Aramaic part of this sentence is ' $p$ qdmtk (at the end of line 68). This is clear, since the particle ${ }^{3} p$ usually occurs at the beginning of a new sentence. ${ }^{51}$ Nevertheless, it has been argued that ${ }^{3} p q d m t k$ has to be connected with $h z y$ and is anal-

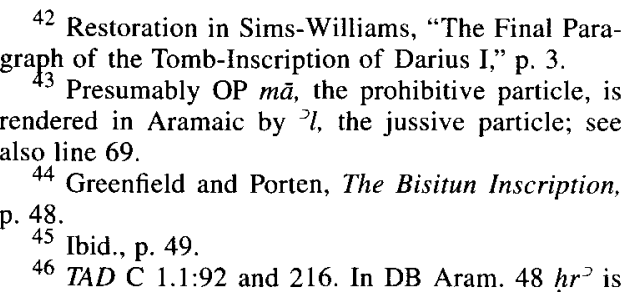
the equivalent of Bab. mār banî (DB Bab. 77). The latter is also attested as the counterpart of muškēnu in DNb Bab. 6.

${ }^{47}$ Nabataean and Palmyrene br hrn (DNWSI, pp. 401-2), Late Aramaic br hwryn (see M. Sokoloff, A Dictionary of Jewish Palestinian Aramaic of the Byzantine Period, Dictionaries of Talmud, Midrash and Targum 2 [Ramat Gan, 1990], p. 99), Hebrew br hwryn (see W. Baumgartner, Hebräisches und aramäisches Lexikon zum Alten Testament [Leiden, 1967], p. 334; J. Levy, Wörterbuch über die Talmudim und Midraschim, 2d ed., vol. 2 [Berlin and Vienna, 1924], p. 239), and Syriac br hryn (see R. Payne Smith, ed., Thesaurus Syriacus, vol. I [Oxford, 1879], p. 53). Cf. also the Ugaritic PN bn hry (J. C. De Moor and K. Spronk, "Problematic Passages in the Legend of Kirtu I," Ugarit-Forschungen 14 [1982]: 168 and n. 126).

${ }^{48}$ In the available space, one can restore approximately twenty-four signs. The proposed restoration already takes up twenty-three signs. If one restored only $h r^{2}$, then the restoration would not fill the available place. The restoration br hry remains the most probable one.

${ }^{49}$ Restoration by Sims-Williams, in "The Final Paragraph of the Tomb-Inscription of Darius I," p. 3.

${ }^{50} \mathrm{E}$. Benveniste, "La racine yat- en indo-iranien," Indo-Iranica: Mélanges présentées à Georg Morgenstierne à l'occasion de son soixante-dixième anniversaire (Wiesbaden, 1964), pp. 22-23.

51 Porten and Muraoka, Grammar, p. 336, par. 90 and n. 1275. See Sims-Williams, "The Final Paragraph of the Tomb-Inscription of Darius I," p. 6. 


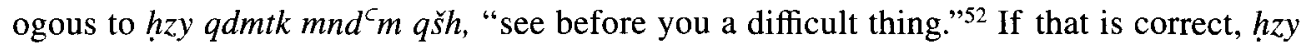
${ }^{2} p$ qdmtk would be a calque on OP avaš-či didiy.

The end of the Aramaic section of DB that draws on DNb poses some problems for scholars. First of all, one should try to determine what exactly was in lines 69-70. Since the scribe started his version of DNb with the beginning of the last paragraph of that inscription (= paragraph 9) and did not omit substantial parts of that paragraph, it is fairly certain that he translated the entire paragraph. As a result, the end of line 69 and the first part of line 70 still have to be part of the Aramaic version of DNb and make up the end of this Aramaic version. This makes it easier to determine the content of these lines. Probably the second half of line 69 contains the equivalent of OP [marika avara]diya mā rax $\vartheta a^{n} t u v(\mathrm{DNb} 59-60),{ }^{53}$ while the Aramaic version of $u\left[t \bar{a}\right.$ dahyauvā mā däriya ${ }^{54}$ was written at the beginning of line 70 .

Unfortunately, both of these lines do not reveal their contents very clearly. The second half of line 69 is badly damaged, and the hitherto proposed readings do not yield a comprehensible sentence..$^{55}$ Furthermore, the first half of line 70 is completely destroyed, except for some small traces of the first letters of that line. ${ }^{56}$

The first sentence of this difficult section consists-as does its Old Persian equivalent [marika avara] diya mā rax $\vartheta a^{n} t u v$ - of three constituents that will be designated below as []d/rklyk, ${ }^{\supset} l$, and $y l X n$.

There are three reasons to believe that the first word ([]d/rklyk) is the subject of this sentence and that the last word $(y l X n)$ is its verbal element. Firstly, the Aramaic translation of this paragraph has exactly the same word order as its Old Persian source, so, accordingly, [] $d / r k l y k$ is the Aramaic rendering of OP marika avaradiya, while $y l X n$ corresponds to rax $\vartheta a^{n} t u v$. Secondly, there is only one example of the verb preceding its subject in DB Aram.: [btlh zy $\left.{ }^{\supset} h w r m z d q t l w h y l^{\supset} z y\right] l y l h\left[y l^{\supset} m r d y^{\supset}\right]$ (line 55). Finally, the spelling $[X] d /$ $r k l y k$ is not likely a verbal form. If this were a verb, the lost letter would have to be a verbal prefix ${ }^{2}, t-$, or $y$-, or the conjunction $w$ - The stem of the verb would be $d / r k l$. But in that case what is the function of the yod that follows? Let us first consider the yod as a verbal element. It cannot be part of the verbal root, so it must be part of a verbal ending. But the only possible forms with an ending $-y$ are jussive or imperative $2 \mathrm{fsg} .{ }^{57}$ It does not seem very likely that we are dealing here with a feminine form, since Darius can hardly have been addressing a female reader. We can safely conclude that $[X] d / r k l y k$ is not a verbal but, rather, a nominal form. To analyze this nominal form, we must again examine the function of the yod. It is clear that the $y$ is either a part of the root or that it is the construct state plural ending, followed by a pronominal suffix $-k(2 \mathrm{msg}$.). In the latter case, however, there would not be agreement between the subject and the verb, since a singular verb $(y l X n)^{58}$ would have a plural subject $([X] d / r k l y k)$. Consequently, the yod must belong to the noun.

52 TAD C 1.1:85. Greenfield and Porten, The Bisitun Inscription, p. 49. See Cowley, Aramaic Papyri, p. 259: "see also before thee." Hoftijzer and Jongeling DNWSI, p. 992 ("In Beh 54 of diff. interpret."), have no opinion about this problem.

${ }^{53}$ Restoration by Hinz, in "Die untere Grabinschrift des Dareios," pp. 237-38.

54 Restoration, ibid., p. 238.

55 [ ] rklyk 9 yldn: Sachau, Aramäische Papyrus, p. 196 and Ungnad, Aramäische Papyrus, p. 90 [w]rklyk ${ }^{c}$ yldn (?): Cowley, Aramaic Papyri, p. 253; [ ]rklyk ${ }^{c}$ yl[ ]n: Greenfield and Porten, The Bisitun

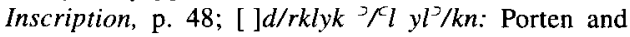
Yardeni, Textbook, vol. 3, p. 70.

${ }^{56}$ Sachau, Aramäische Papyrus, pl. 56 rev. no. 4. Cf. Porten and Yardeni, Textbook, vol. 3, foldout 27.

${ }^{57}$ Muraoka and Porten, Grammar, p. 97 (examples on pp. 104-5 and 107).

58 The verb $y l X n$ almost certainly has to be singular. Most probably it is a jussive (compare the Old 
One can always argue that $[X] d / r k l y k$ is the object of $y l X n$ and that a pronominal suffix attached to the root $d / r k l$ is thus perfectly possible: "He will not $y l X n$ your $[X] d / r k l y$ (plural)." The main objection to this assumption is that the subject of the sentence would not be expressed because $[X] d / r k l y k$ would be the object. Since the subject of $y l X n$, a $3 \mathrm{msg}$. singular, is not the same as in the preceding sentence ( $2 \mathrm{msg}$.), it would be very unusual not to express the new subject the first time it occurs. It thus appears more and more likely that $-y k$ is not a grammatical element but that both letters belong to the noun, whatever that root may be. This conclusion is confirmed by the lack of a possessive pronoun in the corresponding Old Persian sentence.

It can thus be supposed that [ ]d/rklyk is not a verbal form but rather the subject of $y l X n$, that it has the same meaning as OP [marika avara]diya, and that all the letters of this word belong to the stem. This also makes it clear that the second word is $2 l$, the Aramaic jussive particle, and not the preposition ${ }^{C} l{ }^{59}$ This ${ }^{~} l$ nicely corresponds to the Old Persian prohibitive particle $m \bar{a}$.

Hitherto no plausible explanation for []d/rklyk has been found. Since the word is not a construct state masculine plural, all letters belong to the stem, for which a Semitic explanation has not been found ${ }^{60}$ The other possibility - an Iranian loanword-also presents difficulties. The main objection to this possibility is the occurrence of the phoneme $/ l /$, which is not a native Old Iranian phoneme. Yet, since an Iranian $/ r /$ can be rendered by a $/ l /$ in other languages, such as Babylonian ${ }^{61}$ and Elamite, ${ }^{62}$ it might just be possible that such a feature also exists for Aramaic. ${ }^{63}$

The best way to explain this assumed Iranian loanword is to divide the Aramaic form into two parts: []d/rk and $l y k$. This is also attested for other loanwords in Aramaic. Examples are $h d^{\mathrm{D}} \mathrm{bgw}$, "with interest" (TAD A6.13:5), that is composed of Ir. hada, "with," and Ir. *abiga $\bar{v} \bar{a}$, "interest," ${ }^{4}$ and ${ }^{2} r d k l$ (TAD B2.6:2)/ ${ }^{2} r d y k l$, "architect" (TAD B2.8:2), composed of Akk. ardu and Akk. ekallu, "palace." 65

Despite the fact that there is one letter missing, the first part can easily be restored and identified by having a closer look at the Old Persian version, where the subject of the

Persian corresponding version) and the jussive plural ending is $-w$, not $-n$.

59 Ibid., p. 199.

${ }^{60}$ It could be a derivative of $r k l$, "to go about from place to place (for trade or gossip)," which is related to $r g l$, "to slander, to calumniate." The form $r k l y^{3}$ occurs in $T A D$ A4.3:4, where it clearly means "merchants" (DNWSI, pp. 1076-77). But this translation does not fit well with the present text.

61 The Babylonian forms ammaru akal, ammari akal, ammarkaru, and hammarakaru are loanwords from Iranian *hamärakära-. See W. Eilers, Iranische Beamtennamen, pp. 43-59; Greenfield, "*hamarakara > 'amarkal," in M. Boyce and I. Gershevitch, eds., W. M. Henning Memorial Volume (London, 1970), p. 181; Hinz, Altiranisches Sprachgut der Nebenüberlieferungen, Göttinger Orientforschungen, III. Reihe, Iranica, Band 3 (Wiesbaden, 1975), p. 121. Ir. *kārahmāra- appears in Babylonian texts as kalammaru, karammaru, and karri ammaru. See Stolper, "Three Iranian Loanwords in Late Babylonian Texts," in L. D. Levine, ed., Mountains and Lowlands: Essays in the Archaeology of
Greater Mesopotamia, Bibliotheca Mesopotamica 7 (Malibu, California, 1977), pp. 259-66. The Achaemenid Aramaic form of *hamārakāra, hmrkr- is always written with an $r$ (DNWSI, pp. 284-85).

${ }^{62}$ Examples from the Elamite language are listed in M. Mayrhofer, Onomastica Persepolitana: Das altpersische Namengut der Persepolistäfelchen, Österreichische Akademie der Wissenschaften, Phil.-hist. Klasse, Sitzungsberichte 286 (Vienna, 1973), p. 301.

63 The only possible example in Imperial Aramaic is ' $\ln p$ (Stela from Daskyleion, line 1), which might stand for Ir. Arnapa; see J. Teixidor, "Bulletin d'épigraphie sémitique," Syria 45 (1968): 376. The name can also be considered Semitic, meaning "El is exalted" (TSSI, p. 157).

${ }^{64}$ Hinz, Altiranisches Sprachgut, p. 109.

65 A. L. Oppenheim, "Akkadian arad ekalli $=$ 'Builder'," Archív Orientálni 17 (1949): 227-35; S. A. Kaufman, The Akkadian Influences on Aramaic, Assyriological Studies 19 (Chicago, 1974), pp. 35 and $150-51$. 
sentence is marika. The form [m]rk is without a doubt the Aramaic transcription of OP marika. The second part is more difficult to explain: it is possibly a cognate of Av. raēk-, "im Stich lassen," or irik-, "dem Verderben preisgebend." an Iranian word different from the one used in the Old Persian version does not invalidate this assumption. The same feature can be seen in DNb El. 8-9, where the equivalent of the Old Persian adjective manauviš (line 13) is te-iz-za-ma-in-da. This form is not an Elamite word, since in that case it would have to be a verbal form ( $2 \mathrm{sg}$.). It is more likely a transcription of Ir. *taiža $a^{h}$ vant, "having sharpness." ${ }^{\circ 7}$ Another example is the Ir. *humāna- "good dwelling-place, village,"68 which is written hu-ma-nu-iš (DB El. I 25, II 25) and ú-ma-nu-iš (DSf El. 40) in Elamite and is used to translate the OP avahana- "village" (DB OP II 33; DSf OP 46) as well as didā- (DB OP I 58). Finally, a third example is Ir. *hatra-mani- "follower, ally," 69 written ha-tar-ri-man-nu (several times in DB El.) in Elamite and rendering OP anušiya- (several times in DB OP).

According to the photographs, possible readings for $y l X n$ are $y l^{\supset} n, y l b n, y l y n(?), y l d n$, $y l k n, y l^{\complement} n$, or $y l m$. Since we are most likely dealing with a jussive $3 \mathrm{msg}$., the verbal root ${ }^{70}$ to which this word belongs has to end in an $-n$. This root has to mean something like "to prosper," since $y l X n$ is rendering OP rax $\vartheta a^{n} t u v$.

Possibly, one should connect the form $y l y n$ with the root lyn. This verb is attested in Hebrew, Ugaritic, Phoenician, and possibly in Akkadian. ${ }^{71}$ In Hebrew, Ugaritic, and Phoenician, its meaning is "to spend the night, to lodge." connection with lyn would require a semantic shift from "to spend the night" to "to thrive." Perhaps the meaning "to be safe" can be extrapolated from "to spend the night." Thus "to be safe" could lead to the meaning "to thrive" or something similar that fits the context and the Old Persian source. This remains hypothetical, however.

The same semantic difficulty goes for connecting $y l X n$ with the root $l b n$, the form being $y l b n$. The verb $l b n$ means "to make bricks." 73 At first glance this has nothing to do with the semantic field of "to thrive, to prosper," unless one makes the semantic jump from "to make bricks," to "to build a house," to "to be able to build," to "to be prosperous, to be in a safe condition." A closer link, however, is provided in Jewish Aramaic, where

${ }_{66} \mathrm{AiW}$, pp. 1479 and 1529.

${ }^{67}$ Hinz, Altiranische Funde und Forschungen (Berlin, 1969), p. 61; idem, Altiranisches Sprachgut, p. 223; R. Schmitt, review of Hinz, Altiranische Funde, in Kratylos 14 (1969-71): 57.

${ }^{68}$ Hinz, Altiranisches Sprachgut, p. 124.

${ }^{69}$ Ibid., p. 119.

70 Idem, "Großkönig Darius," p. 479, believes that this form is a substantive preceded by the preposition $q$. He translates it "over your children." He considers the contents of the last part of $\mathrm{DNb}$ to be as follows: Darius threatens the subject, who refuses to listen to his words, with trouble (for him as well as for his children), an unsuccessful life, and even exile. There are, however, two arguments against Hinz's theory. Firstly, the correct Aramaic expression for "über deine Kinder" would be 'l yldyk, which does not appear in the text. Secondly, in the other versions of $\mathrm{DNb}$, there does not seem to be any trace of threats against children. The only threats in the last sentence of DNb are uttered against a rebellious man and include an unsuccessful life (mā rax $\left.\theta a^{n} t u v\right)$ and exile (mā dāraiya).
${ }^{71}$ Its occurrence in Akkadian depends on the way one interprets CT 18,6 rev. 6 . The signs read clearly li-a-nam = a-la-[a-ku]. The $A H w$., p. 540 proposes a connection between this lianam and the Hebrew and Ugaritic verbs $l y n$ and gives "nachts gehen" as translation for lianu. This would be the only occurrence of this word in Akkadian, however. For that reason the $C A D$, vol. L, p. 163, proposes an emendation of the text into $\check{s} a-a-h \underline{h} u$, based on $\breve{s} a-a-h b u$ (Malku II 94). The problem here is that two of the three signs would be incorrectly written.

${ }^{72}$ F. H. W. Gesenius, Hebräisches und aramäisches Handwörterbuch über das Alte Testament, 17th ed. (Leipzig, 1921), p. 385; C. H. Gordon, Ugaritic Textbook, vol. 3, Analecta Orientalia 35 (Rome, 1965), p. 428.

${ }^{73}$ Heb. lbn (Gesenius, Hebräisches und aramäisches Handwörterbuch, p. 377), Akk. labānu (CAD, vol. L, p. 8), Ugaritic lbn (Gordon, Ugaritic Textbook, pp. 426-27), Jewish Aram. lbn (M. Jastrow, A Dictionary of the Targumim, the Talmud Babli and Yerushalmi, and the Midrashic Literature [New York, 
the root $l b n$ (as a denominative of לִבְנָא, "brick") can also mean "to have a strong rest, to be well balanced." 74 This meaning is not exclusively architectural, which may support the connection $y l b n$ - $l b n$, as then the step is smaller in order to arrive at the meaning "to be prosperous." Yet this meaning has hitherto only been attested in Jewish Aramaic and would, if accepted for this particular passage, be the only attestation of it in Imperial Aramaic.

As already mentioned above, the lost first half of line 70 must be the equivalent of dahyauvā mā dāriya. In all probability, the construction for OP dahyauva $\bar{a}$ is [bmt $\left.{ }^{\supset}\right] . M t$, a loanword from Akk. $m \bar{a} t u,{ }^{75}$ is also the Aramaic equivalent of OP dahyāuš in DB Aram. 29 and 62. The verb of this sentence, "to dwell," is preserved only in the Babylonian version of DNb: uššabi (DNb Bab. 39). Based on equating ašib (DB Bab. 71) with ytb (DB Aram. 36), the restoration $y t b$ in this passage looks fairly plausible. ${ }^{76}$ Thus the line reads $\left[w b m t^{\supset}{ }^{\supset} l y t b\right]$.

The complete text of DB Aram. 66b-70a follows below.

(66) $\left[\right.$ šgy $\left.^{\supset}\right]$ hwd ${ }^{\complement}{ }^{\supset}$ yk zy ${ }^{\complement}$ byd ${ }^{\supset} \mathrm{nt} \mathrm{w}^{\supset}[\mathrm{yk}]$ hlktk

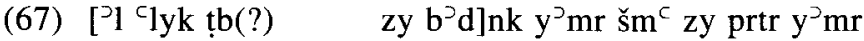

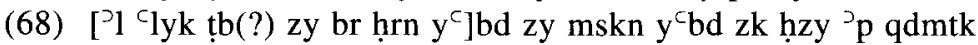

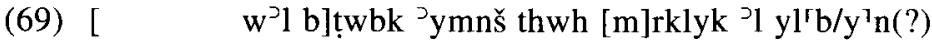

(70) $\left[w^{\prime b m t}{ }^{\supset} \supset \mathrm{ltb}\right]$

\section{DB Aram. 70b-73: The Advice Not to Conceal the Truth}

Here the end of the Aramaic translation of DNb has been reached. Thus, at least from now on, the Aramaic text is again based on the Babylonian version of DB. The first legible sequence of letters in line 70 is hry or perhaps $h r w$. Unfortunately, it is impossible to be sure whether these letters constitute one word or only a part of a word. The second word was read $t[q s]^{2}$ by Sachau. ${ }^{77}$ Porten and Yardeni read $t q y n^{2}$, but they did not translate it. ${ }^{78}$

The form $t q y n^{3}$, however, can be derived from the root $t q n$, a well-attested root in Semitic. In Biblical Aramaic, this root occurs only once, ${ }^{79}$ having the meaning "to restore, to reestablish." 80 In Jewish Aramaic it has the meaning "to prepare, to put in order, to establish, to place." ${ }^{81}$ The root is also attested in Hebrew and means "to make straight,

1926], p. 689; Sokoloff, A Dictionary of Jewish Palestinian Aramaic of the Byzantine Period, p. 276), Arab. labana (Hava, Arabic-English, p. 676). Cf. also Official Aram. lbnh (DNWSI, p. 564).

74 Jastrow, A Dictionary of the Targumim, the Talmud Babli and Yerushalmi, and the Midrashic Literature, p. 690.

75 H. Zimmern, Akkadische Fremdwörter als Beweis für babylonischen Kultureinfluss (Leipzig, 1915), p. 9; Kaufman, Akkadian Infuences, p. 71.

${ }^{76}$ See $D N W S I$, p. 475 , s.v. $y s ̌ b$, for more on this verb.

${ }^{77}$ Sachau, Aramäische Papyrus, p. 196. Ungnad, Aramäische Papyrus, p. 90, has $t q$ 's, but this may be a typographical error (Greenfield and Porten, The Bisitun Inscription, p. 49). Cowley (Aramaic Papyri, p. 253) as well as Greenfield and Porten (The Bisitun
Inscription, p. 49) considered only the tav as being certain; see Porten and Yardeni, Textbook, vol. 3, p. 70 and liv (Glossary): tqyn?

${ }^{78}$ Ibid., p. 70 and liv (Glossary).

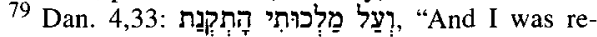
established in my kingdom."

${ }^{80}$ Gesenius, Hebräisches und aramäisches Handwörterbuch, p. 930.

${ }^{81}$ J. A. Fitzmyer and D. J. Harrington, A Manual of Palestinian Aramaic Texts (Second Century B.C.Second Century A.D.), Biblica et Orientalia 34 (Rome, 1978), no. 60:4: wtqn ythn wšlh lmhnyh, "prepare them and send them to the camp"; Jastrow, A Dictionary of the Targumim, the Talmud Babli and Yerushalmi, and the Midrashic Literature, p. 1692; Sokoloff, A Dictionary of Jewish Palestinian Aramaic of the Byzantine Period, pp. 589-90. 
to set in order." 82 In Akkadian, there is the verb taqänu, "to be in order, to put in order (D)", 83 the adjective taqnu, "safe"; 84 a substantive tuqnu, "safety"; 85 and another adjective tuqqunu, "of good quality." ${ }^{\circ 6}$ If we do connect tqyn with the root tqn, it will probably be an adjective (with a $q^{\partial} t \bar{l}$ or a qattil base) ${ }^{87}$ with the meaning "safe, firm." 88

There are two objections to this interpretation. Firstly, this meaning of the word seems hard to reconcile with the contents of DB, but of course we also do not know precisely what is said in the preceding part of the sentence. The second objection is that the $q$ would have been badly written; the right part of the letter is much smaller than usual.

There is, however, another solution that has the advantage of yielding a comprehensible sentence, i.e., [mn $\left.{ }^{3} n t m l k z y{ }^{3}\right] h r y t^{\top} h^{\top}[w h]$, "whoever you are, O king who will come after me" (cf. line 64). Such a restoration would at least fit the context well. The restored phrase is a good transition from the translation of DNb to the resumption of the translation of DB Bab., even despite the fact that such a distinction is not to be found right at the beginning of the account of $\mathrm{DNb}$.

The word following $t^{\top} h^{1}[w h]$ - at the same time the first word of a new sentence-was read $k d b t^{2}$ by Sachau and connected by him with Bab. pirșātu, "lies" (DB Bab. 99). ${ }^{89}$ In his eyes, the scribe was translating part of Babylonian section 45, more precisely the Babylonian sentence šina pirșātu la taqabbi, "do not say they are lies." This proved to be incorrect after Greenfield and Porten made use of an infrared photograph, which yielded the reading $s w d t^{2} / s w r t{ }^{2} .^{90}$ Several solutions to this problem have been offered. Greenfield and Porten try to consider the second letter as a $p$ and connect the resulting $s p r t^{\supset}$ with Bab. šațāru ša ina narî, "the inscription on the relief" (DB Bab. 98 and 100). They refer to Aramaic mly spr $r^{\supset} y$ bns $b^{\supset} z n h$, "the words of the inscription which is on this stela" (KAI 222:I C 17), but a problem with this is that "spr with the meaning 'inscription' always occurs in the masculine." ${ }^{91}$ Another proposal was made by Lemaire, who wanted to read it as $s \dot{p} \dot{r} \dot{y}$, the masculine form. ${ }^{92}$ This, however, is not compatible with the traces visible on the photograph. The word after $s \dot{p} \dot{y}$ ' is irretrievable. Perhaps a form of the verb "to protect" should be restored.

${ }^{82}$ Gesenius, Hebräisches und aramäisches Handwörterbuch, p. 288; DNWSI, p. 1228; Jastrow, A Dictionary of the Targumim, the Talmud Babli and Yerushalmi, and the Midrashic Literature, pp. 1691-92. ${ }_{83} A H w$. p. 1323.

84 Only twice attested in a Neo-Assyrian oracle (SAA 91 vi 22-24): aklu taqnu takkal mê taqnüti tašatti "you will eat safe bread, you will drink safe water" (AHw., p. 1324).

${ }^{85}$ Used as a word in Neo-Assyrian texts (for example, SAA 91 iv 3) and as a part of personal names both in Neo-Assyrian (ADD 414 R.E.1: Tuqnu-ēreš; SAA 76 ii 6': mTuqunu-ēreš) and Neo-Babylonian ( ${ }^{T}$ Tuqnaia: Dar 379:39; mTuqnu-ě̌š: BE 8/1, 158:36; VAS 4,45:8. M. Jursa, Die Landwirtschaft in Sippar in neubabylonischer Zeit, AfO Beiheft 25 (Vienna, 1995), nos. 59:12 and 60:10; mTuqnu- d Šar: Jursa, Die Landwirtschaft, no. 45:4; muqnu- ${ }^{\mathrm{d}}$ Nanaia: BM 74524:21, cf. Jursa, Die Landwirtschaft, p. 219).

${ }^{86} A H w$., p. 1372 has "geordnet, in Lagen gelegt," based on BE 8, 154:3: SÍG tabarri tuqqunātu. Apparently the $A H w$. overlooked PBS 2/1, 208:6 and 9, which is dealing with $5 \mathrm{ME} \mathrm{KU}_{6}$. HI.A tuqqunu. In this phrase, tuqqunu cannot mean "geordnet" but has to mean "of good quality," see G. Cardascia, Les Archives des Murašñ: Une famille d'hommes d'affaires babyloniens à l'époque perse (455-403 av. J.-C.) (Paris, 1951), p. 171.

${ }^{87}$ F. Rosenthal, A Grammar of Biblical Aramaic, 6th ed., Porta Linguarum Orientalium 5 (Wiesbaden, 1995), p. 26.

88 Cf. תַ: (1) "established, firm" (2) "right, good" (Jastrow, A Dictionary of the Targumim, the Talmud Babli and Yerushalmi, and the Midrashic Literature, p. 1690).

${ }^{89}$ Sachau, Aramäische Papyrus, p. 196; Ungnad, Aramäische Papyrus, p. 90; and Cowley, Aramaic Papyri, p. 253, supported this theory.

${ }_{90}$ Greenfield and Porten, The Bisitun Inscription. p. 49 .

91 Ibid.

92 A. Lemaire, review of Greenfield and Porten, The Bisitun Inscription, in Or., n.s., 55 (1986): 349. 
The first word of the next sentence is only partly preserved and is followed by ${ }^{\mathrm{C}} z{ }^{\mathrm{C}} b d t{ }^{1}$, "what I did." ${ }^{93}$ As pointed out by Greenfield and Porten, the verb preceding this relative phrase is "believe" (corresponding to Bab. 101: atta qïpi ša anāku èpušu). The most recent reading is $z y^{3} n h{ }^{\circ} b d t .^{94}$

I do not agree with this restoration. The visible parts of the letters should rather be read ${ }^{\top} h^{\top} y^{\top} m n^{\top}$, that is the haf ${ }^{\complement} \bar{e}$ imperative of ${ }^{2} m n$, a verb commonly used in Semitic languages to express belief and trust. ${ }^{95}$ The beginning of line 71 reads ${ }^{\top} z y{ }^{\complement} b d t^{\top}$. Here the personal pronoun expressing the subject ( $\left.{ }^{2} n h\right)$ is not given, as is also the case in DB Aram. 19, 26, 29 , and 31 .

There is not much to discuss in Aramaic lines 71-73. The text is clearly based on the Babylonian text, and despite the damaged state of the papyrus, the lacunae in these lines have been restored without great difficulty.

The lacuna in line 72 was restored $y\left[b r k n k w z r^{\complement} y h w h l k\right] \check{s} g y$ by Greenfield and Porten, but a proposal by Wesselius ( $\left.y b\left[r k w y r h m n k w z r^{C} k y\right] \breve{s} g^{\text {ग }}\right)$ is more convincing, since it is a reconstruction "almost completely in accordance with Akkadian line 102: "uramazda lusaddidka lu mādu lira ${ }^{2} a m k a ~ u$ NUMUN-ka limid." 96 Porten and Yardeni restore $y b[r k n k]$, which is analogous to $y q[\ln k] \cdot{ }^{97}$ Greenfield and Porten, as well as Wesselius, expect an $s$ here instead of a $b$, but since that $b$ looks quite clear, they have accepted it. ${ }^{98}$ This $s$ would have been part of the verb $s^{c} d$ "to help," which is, according to Greenfield and Porten, the Aramaic phonological cognate of Bab. lusaddidka. Line 73, the last line of paragraph 13, can also be reconstructed in accordance with the Babylonian text ${ }^{\top} h w r m z d$ yq[ $l \ln k w z r^{C} l$ P yhwhlk]. ${ }^{99}$

\section{Conclusion}

Having undertaken an attempt to obtain a clearer interpretation of this text, the results have been put together here. The text and translation of DB Aram. paragraph 13 follow below.

Text

(64) [dryhwš mlk ${ }^{\supset} \mathrm{kn}^{\supset} \mathrm{mr} \mathrm{mn}{ }^{\supset} \mathrm{n}$ ]t mlk zy ${ }^{\supset}$ ḥry thwh ${ }^{\supset} \mathrm{yš} \mathrm{zy} \mathrm{ykdb}$

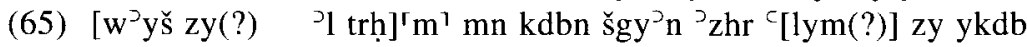

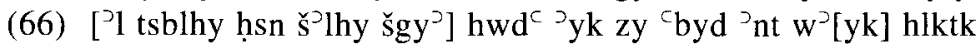

93 According to Porten and Yardeni, Textbook, vol. 3, p. 70. As for 'bdt, Sachau, Aramäische Papyrus, p. 204, no. 4, line 1, read nothing, as did Ungnad, Aramäische Papyrus, p. 93, and Greenfield and Porten, The Bisitun Inscription, p. 48. Cowley, Aramaic Papyri, p. 266, proposed a nun as the last letter.

94 Porten and Yardeni, Textbook, vol. 3, p. 71.

95 Hebrew " $m n$, "to be firm, to be reliable," in the hif ${ }^{\circ}$ ll, "to believe someone, to trust" (Gesenius, $\mathrm{He}$ bräisches und aramäisches Handwörterbuch, p. 48), and "āmèn, "certainly" (ibid., p. 49); Biblical Aramaic (Dan. 6:24: היפרן "he believed"; Dan. 2:45 and 6:5: מְהֵימַ) and Imperial Aramaic (though here only passive participle) "$m n$ (haf ${ }^{c} e l$ ), "to believe" (Gesenius, Hebräisches und aramäisches Handwörter- buch, p. 895; DNWSI, pp. 278-79); Jewish Aramaic "mn (haf $\bar{e} \bar{e}$ ), "to trust, to confide" (Jastrow, A Dictionary of the Targumim, the Talmud Babli and Yerushalmi, and the Midrashic Literature, p. 347); Arabic 'amuna (IV), "to believe."

${ }^{96}$ Greenfield and Porten, The Bisitun Inscription, p. 48; J. W. Wesselius, review of Greenfield and Porten, The Bisitun Inscription, in BiOr 41 (1984): 444.

${ }_{97}$ Porten and Yardeni, Textbook, vol. 3, p. 70.

98 Greenfield and Porten, The Bisitun Inscription, p. 51; Wesselius, review of Greenfield and Porten, BiOr 41, p. 444.

${ }^{99}$ Greenfield and Porten, The Bisitun Inscription, p. 50 . 


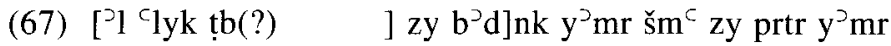

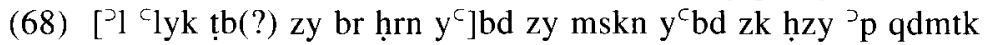

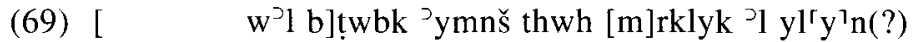

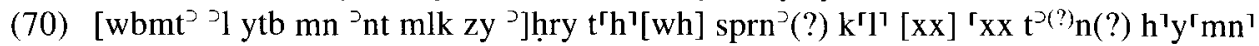

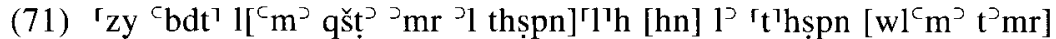

(72) ' hwrmzd yb[rknk wyrḥmnk wzr ${ }^{\complement} k$ y]šs ${ }^{\supset}$ wywmyk $y^{\supset}$ rkwn wh'n thṣpnhy

(73) ${ }^{\mathrm{T}}$ hwrmzd yq[llnk wzr ${ }^{\complement} \mathrm{l}^{\mathrm{P}}$ yhwh lk]

\section{Translation}

(64-66a) [Thus speaks King Darius: "Whoever yo]u are, O king who will come after me, do not be a friend of the man who lies or to [lawbreakers]. Protect yourself from many lies. [A servant] who lies, [do not support him].

(66b-70a) Firmly make known how you act and how your conduct is. [Let not that be good to you which] one says in your ear. Listen to that which one says in public. [Let not that be good to you what the freeborn man do]es. That which he who is not freeborn does, look at that. For yourself too [ ] and you will not be insecure in your happiness. An evil young man will not prosper(?) [and in the land he will not live].

(70b-73) Whoever you are, O king who will come after me, our text(?) completely [ ]. Believe what I did [and tell the truth to the people. Do not conceal] it. [If] you do not conceal it [but tell it to the people], Ahuramazda will bl[ess you. He will befriend you and your descendants will be] numerous, your days long lasting. But if you do conceal it, Ahuramazda will cu[rse you, and there will not be any offspring for you].

Finally, in Table 1 below, I have provided the Aramaic text and its equivalents in its source-texts, the Babylonian text of DB and the Old Persian text of DNb. The Babylonian line numbers are given in parentheses.

TABLE 1

\begin{tabular}{|c|c|}
\hline DB Aramaic Paragraph 13 & Source Text \\
\hline DB Aramaic $64-66 a$ & DB Babylonian $97,105-6$ \\
\hline (64) [dryhwš mlk ${ }^{\supset} \mathrm{kn}^{\supset} \mathrm{mr}$ ] & dariamuš šarru kīam iqabbi \\
\hline$\left[\mathrm{mn}^{\supset} \mathrm{n}\right] \mathrm{t}$ mlk zy ${ }^{\supset}$ hry thwh & mannu atta šarru ša arkia tellâ ( 97 or 105, secs. 44 or 52 ) \\
\hline 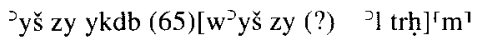 & amēlu ša uparrașu u amēlu pirkāni 「la ta'râm (105-6, sec. 52) \\
\hline mn kdbn šgy ${ }^{\supset} n{ }^{2} \mathrm{zhr}$ & lapani pirșātu lu mādu uṣur ramanka (97, sec. 44) \\
\hline$\left[{ }^{C} \operatorname{lym}(?)\right]$ zy ykdb (66) [ ${ }^{\top} 1$ tsblhy] & la [tusad] ${ }^{\top} \mathrm{dad}^{\top}$ amēlu ša uparra'șu' $(97$, sec. 44$)$ \\
\hline [hsn š $\breve{s}^{\top}$ hy] & lu $\mathrm{m}^{\Gamma} \mathrm{a} \mathrm{a} \mathrm{du}$ šălšu (line 97, sec. 44$) ?$ \\
\hline DB Aramaic $66 \mathrm{~b}-70 \mathrm{a}$ & DNb Old Persian $50-60$ \\
\hline$\left[\check{s ̆ g y}^{\supset}\right]$ hwd $d^{c}{ }^{\supset} y k$ zy ${ }^{\complement}$ byd ${ }^{\supset}$ nt $w^{\supset}[y k]$ hlktk & 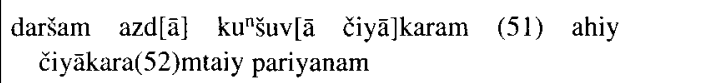 \\
\hline (67) $\left[{ }^{\supset} 1^{\complement} \mathrm{lyk}\right.$ ṭb(?) zy $\left.b^{\supset} \mathrm{d}\right] \mathrm{nk} \mathrm{y}^{\supset} \mathrm{mr}$ & $\begin{array}{l}\text { mātaiy [ava vahiš] tam (53) } \theta \mathrm{a}^{\text {ndaya tyataiy gaušāyā }} \\
\quad \theta \text { [ahyātiy] }\end{array}$ \\
\hline$\breve{s m}^{\complement} z y$ prtr $y^{\supset} \mathrm{mr}$ & avaš(54)čiy āxšnūdiy hya pa[ratar $\theta$ ahy]āti(55)y \\
\hline (68) $\left[{ }^{\top} 1^{c}\right.$ lyk țb(?) zy br ḥrn $\left.y^{c}\right] b d$ & màtaiy ava [naibam $\theta a^{n}$ daya tya da $\theta a(56)^{n} \mathrm{~s}$ ?] $\mathrm{ku}[$ na]vātaiy \\
\hline
\end{tabular}




\begin{tabular}{|c|c|}
\hline zy mskn y'bd zk ḩzy & 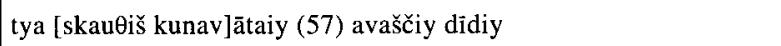 \\
\hline 'p qdmtk [...] & mā (58) parāyātaya a-[5 tekens] \\
\hline 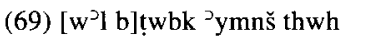 & mā[patiy š]iyātiyā (59) ayāumainiš bavāhiy \\
\hline$[\mathrm{m}] \mathrm{rklyk}{ }^{\supset} \mathrm{l} \mathrm{y}^{\mathrm{r}} \mathrm{y}^{\top} \mathrm{n}(?)$ & [marika avara]diya (60) mā rax $\theta$ atuv \\
\hline (70) [wbmt $\left.{ }^{\supset}{ }^{\supset} \mathrm{ytb}\right]$ & u[tā dahyauvā mā dāra]iya (DNb 60) \\
\hline DB Aramaic $70 \mathrm{~b}-73$ & DB Babylonian 97, 101-3, 105(?), 106(?) \\
\hline$\left[m n{ }^{\supset}\right.$ nt mlk zy $\left.{ }^{\supset}\right]$ hry $t^{\top} h^{\top}[w h]$ & mannu atta šarru ša arkia tellâ ( 97 or 105 , secs. 44 or 52 ) \\
\hline $\left.\operatorname{sprn}^{\supset}(?) \mathrm{k}^{\Gamma}\right]^{\top}[\mathrm{xx}]^{\mathrm{r}} \mathrm{xx} \mathrm{t}^{\supset(?)} \mathrm{n}(?)^{1}$ & su[ddissunūtu]? (106, sec. 53) \\
\hline${ }^{\top} h^{\top} y^{\top} \mathrm{mn}(71) z^{C}{ }^{C} d t^{\top}$ & atta qīpi ša anāku ēpušu (101, sec. 49) \\
\hline $\left.1\left[{ }^{c} \mathrm{~m}^{2} \mathrm{q} \mathrm{s}^{2}\right]^{2} \mathrm{mr}\right]$ & u amātu kittu ana uqu qībì (101-2, sec. 49) \\
\hline$\left[{ }^{\top} 1 \text { thṣpn }\right]^{r} l^{\top} h$ & 'ul' tapissin $(102$, sec. 49$)$ \\
\hline [hn] $\mathrm{l}^{P} \mathrm{r}_{\mathrm{t}} \mathrm{h}$ șpn $\left[\mathrm{wl}^{\mathrm{C}} \mathrm{m}^{2} \mathrm{t}^{\supset} \mathrm{mr}\right]$ & 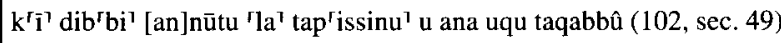 \\
\hline (72) ' ${ }^{\supset}$ wrmzd ybrknk & duram[az]da ${ }^{1} l u^{\prime}$ saddidka $(102$, sec. 49$)$ \\
\hline [wyrḥmnk] & lu mādu lirāmka $(102$, sec. 49$)$ \\
\hline$\left[w_{z r}{ }^{\complement} k\right.$ y $] \mathrm{sg}^{\supset}$ & 'u zēruka' [li]mīd (102, sec. 49) \\
\hline wywmyk $y^{\supset}$ rkwn & ūmē[ka] līrikū $(102$, sec. 49$)$ \\
\hline wh' $^{\top}$ thșpnhy' & u kī dibbi annūtu tapissinu (102, sec. 49) \\
\hline (73) 'hwrmzd yq[1lnk] & duramazda lī'ru'rka (103, sec. 49) \\
\hline$\left[\mathrm{wzr}^{\mathrm{c}} \mathrm{l}^{\supset}\right.$ yhwh $\left.\mathrm{lk}\right]$ & zēruka lū iānu (103, sec. 49) \\
\hline
\end{tabular}

